\title{
Corporate Governance, Corporate Social Responsibility and Corporate
}

\section{Performance study}

\author{
Tiantian Xia ${ }^{1, a}$, Xiaomei Luo ${ }^{2, b}$, Yujie Liao ${ }^{3, c}$ and Wenlong Liu ${ }^{4, d}$
}

${ }^{1}$ Xia Tiantian(1989-),Business School Netherlands Ph.D Candidates, Nanchang Institute of

Technology Institute of Finance,Lecturer,Research field is Business management,Nanchang 330000 , China

${ }^{2}$ Luo Xiaomei(1994-), Nanchang Institute of Technology Institute of Finance, Student, research field is Business Management,Nanchang 330000,China

${ }^{3}$ Liao Yujie(1996-), Nanchang Institute of Technology Institute of Finance, Student, research field is Business Management,Nanchang 330000,China

${ }^{4}$ Liu Wenlong(1986-), Nanchang Institute of Technology Institute of Finance,Lecturer,Research field is Business management,Nanchang 330000 , China

akidd1989730@qq.com ,b1210524518@qq.com

Key words: corporate governance, corporate social responsibility, corporate performance

\begin{abstract}
Corporate governance as a modern enterprise can not be ignored management problems, how to enhance their own business performance is an eternal research problem..Based on the analysis of relevant research results at home and abroad, this paper takes the data of 260 listed companies in A shares as the research sample. Based on the theory of corporate social responsibility and stakeholder theory, this paper constructs the relevant index system, The data were collated and analyzed by AMOS 17.0 software. According to the results, it was found that there was a significant positive correlation between corporate governance and corporate performance. At the same time, corporate social responsibility played a completely mediating effect between the two.
\end{abstract}

\section{Introduction}

Since the 1980s, corporate governance has become the subject of research all over the world. Corporate governance is extremely important to the development of the company ${ }^{[1][2]}$. If the concept of corporate governance, the establishment of the system or the mechanism ignores the restrictions on the desire of interests, it is easy to violate the principle of economic market operation and eventually cause great losses to the company's stakeholders, So the study of corporate governance can improve the corporate social responsibility from within the company to enhance the business performance $^{[3][4]}$. The current research is to discuss corporate governance and corporate social responsibility separately, to examine its impact on financial performance independently, and lack of theoretical support leads to the absence of safeguard measures for corporate social responsibility in the existing corporate governance mechanism, Therefore, it is an inevitable problem to study the relationship between corporate governance and corporate financial performance from the perspective of intermediary ${ }^{[5]}$. 


\section{Theoretical Review and Research Hypothesis}

Corporate governance as a combination of institutional mechanisms is to ensure that the interests of shareholders for the purpose of a way to govern the company, it through a specific organizational structure, and then the formation of checks and balances ${ }^{[6]}$;It can be seen that corporate governance is the means of coordinating the rights and interests of stakeholders, coordinating the stakeholder relations tools;And today, corporate social responsibility as an important obligation to do business, the degree of its attention to the enterprise and the actual performance of enterprises have a significant positive impact on the relationship ${ }^{[7][8]}$.According to Hill (2007) it can be seen that the perceived quality of corporate social responsibility investment is considered to be the most effective way for investors to evaluate enterprises ${ }^{[9]}$. With the increase of investment in social responsibility, the image of enterprises will be optimized, And thus form the enterprise can not imitate the core competitiveness, and ultimately enhance business performance.

Therefore, this paper uses corporate social responsibility as an intermediary variable to explore the impact of corporate governance and corporate performance ${ }^{[10]}$. Theoretically analyze the impact of each variable on the performance of the enterprise, and use the data of the listed company to verify it. And put forward the following research hypothesis:

$\mathrm{H}$ 1: Corporate governance is positively correlated with corporate performance.

$\mathrm{H}$ 2: Corporate social responsibility between corporate governance and corporate performance, play the role of intermediary effect.

\section{Research variables and data analysis}

In this paper, CSMAR database is used to select the listed financial data of 260 listed companies in 2015 as the research sample, and the relevant index system is established. The relationship between corporate governance, corporate social responsibility and corporate performance is verified by SEM method. The constituent indicators are shown in Table 1 below:

TABLE 1 Each variable is defined

\begin{tabular}{|c|c|c|c|c|c|}
\hline \multicolumn{2}{|c|}{ Variable type } & Variable name & $\begin{array}{c}\text { Indicator } \\
\text { symbol }\end{array}$ & Metrics & Calculation formula \\
\hline \multirow{4}{*}{$\begin{array}{l}\text { Independent } \\
\text { variable }\end{array}$} & \multirow{4}{*}{$\begin{array}{c}\text { Corporate } \\
\text { Governance } \\
\text { (CG) }\end{array}$} & Ownership structure & FIR & Equity concentration & Shareholding of the largest shareholder \\
\hline & & Board structure & SD & Board size & Total number of board members \\
\hline & & $\begin{array}{c}\text { The effectiveness of the } \\
\text { board of directors }\end{array}$ & IDR & $\begin{array}{c}\text { The size of the board } \\
\text { of supervisors }\end{array}$ & $\begin{array}{l}\text { The size of the board of supervisors } \\
\text { Total number of directors }\end{array}$ \\
\hline & & $\begin{array}{c}\text { Supervisory Board } \\
\text { structure }\end{array}$ & SUPSIZE & $\begin{array}{l}\text { Size of Board of } \\
\text { Supervisors }\end{array}$ & Total Number of Board of Supervisors \\
\hline \multirow{6}{*}{$\begin{array}{l}\text { Mediation } \\
\text { variable }\end{array}$} & \multirow{6}{*}{$\begin{array}{c}\text { Corporate } \\
\text { society } \\
\text { responsibility } \\
\text { (CSR) }\end{array}$} & $\begin{array}{c}\text { Responsibility for } \\
\text { shareholders }\end{array}$ & EPS & $\begin{array}{l}\text { Earnings } \\
\text { per share }\end{array}$ & Net profit / Share capital \\
\hline & & $\begin{array}{l}\text { The responsibility of the } \\
\text { creditor }\end{array}$ & DAR & Assets and liabilities & $\begin{array}{l}\text { Payment to employees and cash paid for } \\
\text { employees / Operating income }\end{array}$ \\
\hline & & $\begin{array}{l}\text { Responsibility for the } \\
\text { supplie }\end{array}$ & APR & $\begin{array}{l}\text { Accounts payable } \\
\text { turnover rate }\end{array}$ & Operating cost / Operating income \\
\hline & & $\begin{array}{l}\text { Responsibility for the } \\
\text { customer }\end{array}$ & IRR & $\begin{array}{l}\text { Operating income } \\
\text { growth rate }\end{array}$ & Operating cost/ Operating income \\
\hline & & $\begin{array}{l}\text { The responsibility of the } \\
\text { staff }\end{array}$ & EMP & $\begin{array}{l}\text { Employee income } \\
\text { ratio }\end{array}$ & Operating income/ accounts payable \\
\hline & & $\begin{array}{l}\text { The responsibility of the } \\
\text { government }\end{array}$ & TAX & Tax rate & $\begin{array}{l}\text { (Pay the taxes - Received tax returns) } \\
\text { Operating income }\end{array}$ \\
\hline
\end{tabular}




\begin{tabular}{|c|c|c|c|c|l|}
\hline & & $\begin{array}{c}\text { The responsibility of the } \\
\text { public }\end{array}$ & COM & Donation ratio & Donate expenses / Operating income \\
\hline \multirow{2}{*}{$\begin{array}{c}\text { Dependent } \\
\text { variable }\end{array}$} & Performance & Profitability & ROE & $\begin{array}{c}\text { Rate of Return on } \\
\text { Common } \\
\text { Stockholders' Equity }\end{array}$ & Net profit / Average net assets \\
\cline { 3 - 6 } & (CP) & ROA & $\begin{array}{c}\text { Return on Total } \\
\text { Assets }\end{array}$ & Net profit / Average total assets \\
\cline { 3 - 6 } & & Operating capacity & LIQ & Total asset turnover & $\begin{array}{l}\text { Main business income / Average total } \\
\text { assets }\end{array}$ \\
\hline
\end{tabular}

First, after properly sorting the data, Amos 17.0 software was used to analyze the data. From Table 2, it was not difficult to find the relevant data standards of each variable to meet the relevant research standards and requirements, and to carry out further data analysis. Specific data see Table 2:

TABLE 2 Descriptive statistical analysis of each variable

\begin{tabular}{|c|c|c|c|c|c|c|}
\hline \multicolumn{7}{|c|}{ Descriptive statistics } \\
\hline & & $\mathrm{N}$ & MIN & MAX & AVERAGE & STDEV \\
\hline \multirow{4}{*}{ CG } & FIR & 260 & 0.00 & 0.80 & 0.13 & 0.10 \\
\hline & SD & 260 & 5.00 & 20.00 & 9.13 & 1.73 \\
\hline & IDR & 260 & 0.21 & 0.65 & 0.32 & 0.06 \\
\hline & SUP & 260 & 3.00 & 15.00 & 4.33 & 1.22 \\
\hline \multirow{7}{*}{ CSR } & EPS & 260 & 5.84 & 98.81 & 39.71 & 25.21 \\
\hline & DAR & 260 & 0.18 & 6.85 & 1.65 & 1.26 \\
\hline & APR & 260 & 0.03 & 22.86 & 2.01 & 3.60 \\
\hline & IRR & 260 & 0.86 & 418.35 & 21.71 & 53.97 \\
\hline & EMP & 260 & 0.08 & 404.36 & 10.41 & 40.79 \\
\hline & TAX & 260 & 0.08 & 5.69 & 1.06 & 0.83 \\
\hline & $\mathrm{COM}$ & 260 & 0.13 & 320.17 & 9.58 & 30.42 \\
\hline \multirow{4}{*}{$\mathrm{CP}$} & ROE & 260 & 0.07 & 2.57 & 0.54 & 0.39 \\
\hline & ROA & 260 & 0.17 & 8.95 & 1.27 & 1.14 \\
\hline & LIQ & 260 & 0.11 & 0.94 & 0.57 & 0.21 \\
\hline & NPS & 260 & 0.01 & 0.62 & 0.15 & 0.11 \\
\hline
\end{tabular}

Secondly, using the Amos 17.0 software to analyze the structural equation of the model, we can see that the model has good goodness of fit $\left(x^{2} / d f=1.37\right.$ 、 $G F I=0.93 、 R M R=0.05 、 R M S E A=0.08$ 、 $\mathrm{NFI}=0.93 、 \mathrm{CFI}=0.85 、 \mathrm{p}=0.000)$, Other data indicators are also in full compliance with Rong Taisheng (2010) on the SEM model of goodness of the model (as shown in Figure 1, Table 3). 


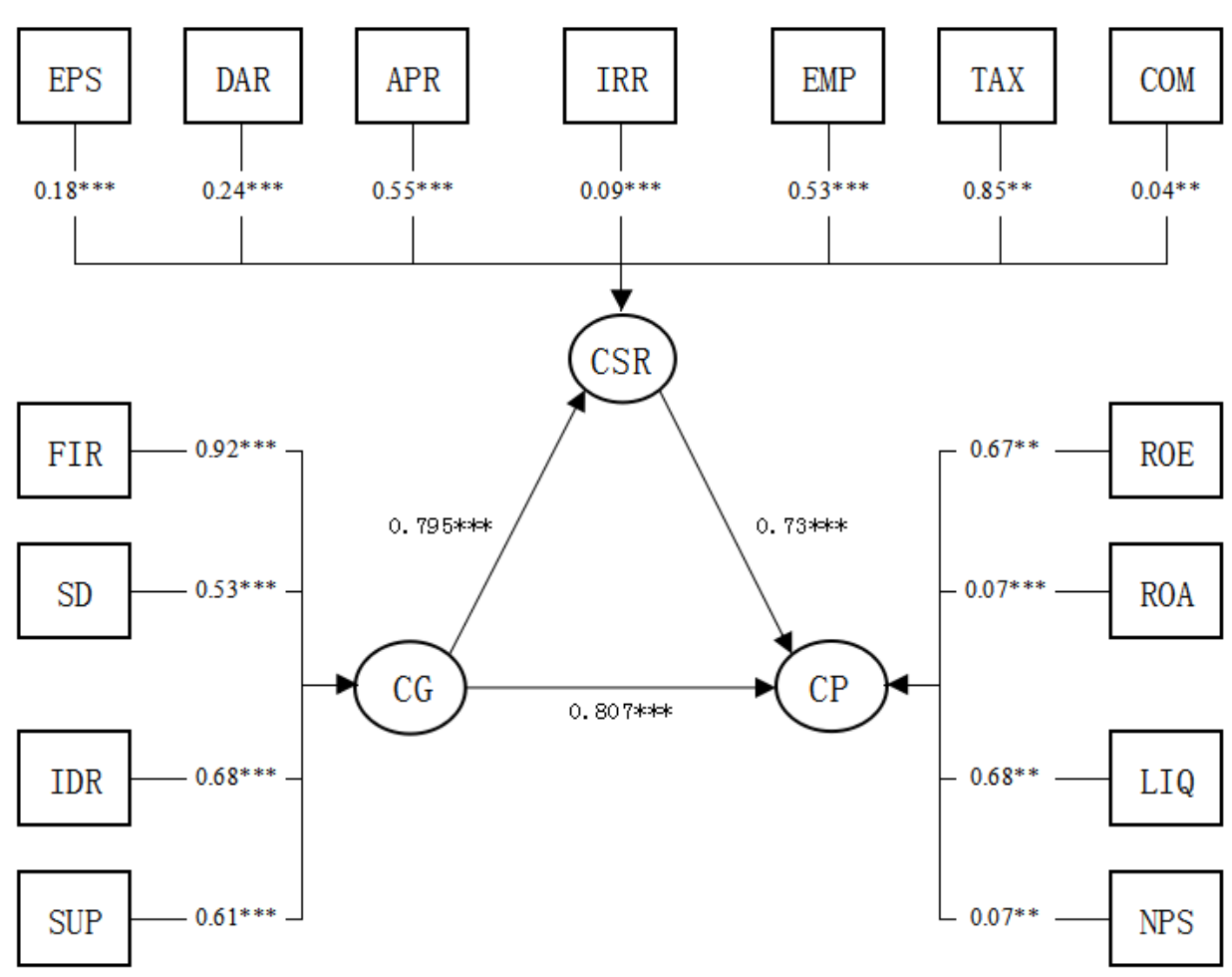

$x^{x} / d f=1.37 、 G F I=0.93 、 R M R=0.05 、 R M S E A=0.08 、 M F I=0.93 、$ CF $I=0.85, p=0.000$

Fig.1 Structural equation model

TABLE 3 Model path coefficient and significance checklist

\begin{tabular}{ccccc}
\hline & Path coefficient & S.E. & C.R. & P \\
\hline $\mathrm{CP} \leftarrow \mathrm{CG}$ & 0.807 & 27.813 & 1.072 & $* * *$ \\
\hline $\mathrm{CSR} \leftarrow \mathrm{CG}$ & 0.795 & 1.022 & 1.778 & $* * *$ \\
\hline $\mathrm{CP} \leftarrow \mathrm{CSR}$ & 0.730 & 8.970 & 4.580 & $* * *$ \\
\hline $\mathrm{CP} \leftarrow \mathrm{CSR} \leftarrow \mathrm{CG}$ & Direct effect: & Indirect effect: & Complete \\
& $0.61 * * *$ & & $0.58 * * *$ & mediation
\end{tabular}

Note: *** is less than 0.01 significant, ** is less than 0.05 significant

Finally, according to the results of SEM analysis, the path coefficient of corporate governance to business performance is $0.807, \mathrm{P}=0.024$, other data indicators also meet the relevant requirements,It can be seen that the two show positive correlation, but also to H1 to be verified;In addition, corporate social responsibility in the intermediary between the two test, according to Wen Zhonglin (2016) for the intermediary effect of the relevant research standards analysis, we can see that corporate social responsibility as a mediator variable between the two played a significant role in mediation (path coefficient 0.58 , P value is 0.017 ); $\mathrm{H} 2$ is verified.

\section{Conclusion}

In recent years, academia and theorists are more concerned about the topic of corporate governance, social responsibility and corporate performance research on the relationship between 
the past, most of the academic papers, the financial performance of listed companies are easy to study, but ignores the social responsibility of the problem, and for corporate governance, social responsibility and corporate performance of the relationship between the three less research, the relationship between the three empirical Analysis has not yet formed a comprehensive and consistent conclusion.Through the theoretical and empirical analysis, the following conclusions are drawn:

(1) In modern corporate governance as a system, to a certain extent, can strengthen the company's internal management constraints, have a positive impact on business performance.

(2) For business, corporate social responsibility is an invisible asset.In the short term, consumers can have a stronger sense of the responsibility of the enterprise, and then create a product sales premium, but also to pool staff strength, improve employee loyalty and thus improve short-term financial performance.In the long term can find new business opportunities, develop new markets, build a bridge with stakeholders to reduce transaction costs, and finally by improving corporate reputation to create business value.

(3) Corporate governance is used as a way for enterprises to balance the institutional arrangements of various stakeholders and to enhance the role of corporate social responsibility in corporate performance;This paper proves that enterprises in the daily production and management process, not only should pay attention to the maximization of the interests of shareholders, but also a lot of consideration should be the interests of various stakeholders, while enterprises in the pursuit of financial results should also consciously and actively assume the social Their duty. And social responsibility does not just mean that we must pay at the expense of economic interests.

If the enterprise has the courage to actively assume social responsibility, not only will increase the financial performance of enterprises, but also get the outside world affirmation, get a positive market reaction.Reasonable adjustment of corporate governance structure, can improve the enterprise management flaw is also imperative, the rational optimization of corporate governance structure will help improve business performance, but also an important basis for enterprise development.

\section{References}

[1] Shelton.The Philosophy of Management[M]. New York: Addisom Wedley, 1924.74

[2] Herbert A Simon. Administrative behavior: A Study of Decision-Making Processes in Administrative Organization [M]. Mechanical industry press.1976.

[3] Freeman, R. E . Strategic Management : A Stakeholder Approach[M] . Pitman Publishing Inc. 1984.

[4] Shleifer, A. and R. W. Vishny. Large share holders and corporate control [J]. Journal of Political Economy, 1986(94): 461-488.

[5] Wu Jinglian modern company and enterprise reform [M] Tianjin: Otsu People's Publishing House 1994.

[6] Lin Yifu, Li Zhou The connotation of modern enterprise system and state-owned enterprise reform direction of economic research, 1997,03: 3-10

[7] Paula L. Rechner. The role of ownership and corporate governance factors in international entry mode selection [J]. The International Journal of Organizational Analysis. 2001, 9 (4) : 89-121. 
[8] Wang Xiongyuan. On Stakeholder Responsibility and Corporate Financial Governance [J]. Accounting Research, 2004 (3): 50-54.

[9] Chen Yuqing, Ma Lili. Empirical Study on Market Response of Social Responsibility Accounting Information of Listed Companies in China [J]. Accounting Research. 2005 (11): 76-81.

[10]Xia Tiantian.A Study of the Impact of Customer Percelved Value on Purchas Intention in Herhal Tea Market Context[D].Jiangxi Normal University.2016. 